\title{
Role of aerospace care nursing in Brazil: Integrative review
}

\author{
Êmille M. de Morais, ${ }^{1}$ Flávia C. P. A. D' ${ }^{\text {Agostini, }}{ }^{2}$ Naila Albertina de Oliveira ${ }^{3-5 *}$
}

\begin{abstract}
Introduction: With mandatory "Flight Nurses" during World War II, there was a need to improve aeromedical rescue. Currently, the use of aerospace removal is crucial to rapidly take away trauma patients in large urban centers. In Brazil, $\mathrm{ABCDE}$ system is adopted during pre-hospital care (PHC) so that nursing needs constant updating to meet the demand for care. Objective: To identify and describe role and challenges of nursing professionals in aerospace transport. Methodology: Integrative review of indexed articles in the last 10 years (2010 to 2020) with focus on pre-hospital care and nursing role. Inclusion criteria were: country of publication, Brazil was the only one considered, publication of the full text and appropriate descriptors. Exclusion criteria included: publication from other countries, absence of descriptors and duplication of articles in databases. Descriptors were crossed in either pairs or trios. Results: A total of 1306 articles on the theme were found, 16 of which were selected by contemplating the research question. However, only 13 met all requirements in the study as excluded articles (1) did not address the research problem in any aspect or (2) were themselves integrative reviews. Conclusion: More studies on needs and particularities of aerospace removal are essential for nurses in order to fill existing knowledge gaps.
\end{abstract}

Keywords: Emergency nursing; Air rescue; Emergency medical services; Transport of patients.

\section{Introduction}

War reports indicate withdrawal and assistance to combatants in battles. During this period, professionals developed methods to provide care and removal through animal traction was originally employed. ${ }^{1}$ In Franco-Prussian war (1870-1871), hot air balloons were used but this fact does not bring much experience with respect to aircraft removals. ${ }^{2}$

Aeromedical Rescue (AMR) only had its definitive appearance in World War II (1939-1945). "Flight Nurses" (professionals specialized in this type of service) operated in cargo planes with three beds on each side. A basic requirement was to attend Flight Nurses School for 6 months at air force hospitals. Only in 1950, the military recognized these professionals' role during the Korean War, in which nursing practice was mandatory. ${ }^{2}$

During Getúlio Vargas' government, General João Batista Mascarenhas de Moraes commanded the Brazilian Expeditionary Force (FEB) and sent 187 health professionals to Italy in 1944, being 67 nurses - 6 of whom
1. Faculdade de Enfermagem, Universidade Paulista. Limeira, SP, Brazil.

2. Departamento de Enfermagem, Faculdade de Enfermagem, Universidade Paulista. Limeira, SP, Brazil.

3. Programa de Pós-Doutorado em Enfermagem, UNIFESP. São Paulo, SP, Brazil.

4. Departamento de Enfermagem Cirúrgica, Escola de Enfermagem, UNIFESP. São Paulo, SP, Brazil.

5. Departamento de Enfermagem da Universidade Paulista. Jundiaí, SP, Brazil.

*Correspondence address:

R. Miguel Guidote, 405

Limeira, SP, Brazil. CEP: 13485-342

E-mail: naila.oliveira@docente.unip.br

ORCID: https://orcid.org/ 0000-0001-8340-5334

BJHBS, Rio de Janeiro, 2021;20(1):63-72

DOI: $10.12957 /$ bjhbs.2021.59747

Received on 12/06/2020. Approved on 02/22/2020.

were specialized in AMR. Before, on October 9,1943 via newspaper "O Globo", the Brazilian government made a call for volunteers to compose FEB in order to comply with the request from the hegemonic group in USA. ${ }^{3}$

On mandatory basis, all these volunteers attended the Army Reserve Emergency Nurse Course (CEERE acronym) and then became reserve nurses. This training aimed at establishing the military habitus to allow responding to war scenario. It pointed to prospective difficulties such as care in airplanes during long flights over the Atlantic Ocean while lacking medical presence. $^{3}$

In 1950, the Brazilian Air Force (FAB) started AMR through Search and Rescue Service (SAR) in Pará State capital by tracking missing aircrafts or vessels. " "Today in Brazil, we already have numerous AMR services thanks to growing technological evolution, which is necessary to standardize rules and protocols to be followed in care offered to patients". ${ }^{5}$

Nowadays, FAB is active in several Aeromedical Evacuation Missions (EVAM) or Mercy Missions (MMI). ${ }^{4}$ Unfortunately, nurses have no training during their undergraduate studies, which are offered in military training of physicians.

Ministry of Health (MS) Ordinance No. 2048/GM of November 52002 stipulates the presence of a pilot, 


\section{Review article}

a doctor and a nurse in traumatic emergencies with primary and secondary mobile pre-hospital care (PHC) ${ }^{6}$ From thematic viewpoint, it also determines the specific training of air medical professionals.

Likewise, on-board nursing is supported by Law No. 7498/86, which regulates Professional Nursing Practice? It defines that organizing and directing client assistance is nurse's exclusive role.

AMR is relatively recent in Brazil and it lacks specific protocols and knowledge regarding on-board nursing. Moreover, Brazilian territory is extensive, thus justifying AMR by its effective and beneficial use to most distant populations.

In view of such relevant context, previously mentioned premises raised the following question: What are on-board nursing skills? Accordingly, this study aimed at identifying and describing roles and challenges of nursing professionals in aerospace transport.

\section{Methodology}

This integrative review searched bibliographic references addressing the role of nursing in aerospace-aeromedical transport in terms of: emergency nursing, air rescue and assistance protocols, interventions used in aeromedical service. The research was carried out in March 2020, covering the period from 2010 to 2020. Integrative reviews aim at condensing knowledge while integrating results from several studies on the intended topic. ${ }^{8}$

The methodology comprises six phases, namely:(1) elaboration of guiding question, (2) search or sampling in the literature, (3) data collection, (4) critical analysis of included studies, (5) discussion of results, and (6) presentation of the integrative review. ${ }^{8}$ Those phases render a better visualization of available content, leading researchers to their objective by either confirming or refuting their hypothesis with the guiding question, namely: what are on-board nursing skills?
PICO uses evidence to support best clinical decision while possibly used in several studies in order to guide the search for answers and hypothesis elaboration. Accordingly, aforesaid acronym is divided into stages in which ' $\mathrm{P}$ ' (patient) refers to nursing, ' $\mathrm{I}$ ' (intervention) corresponds to protocols used, and 'CO' (comparison and outcomes) characterizes on-board nursing role.

In order to list articles, four descriptors were used: (1) emergency nursing, (2) patient transportation, (3) air rescue, and (4) medical services. Those descriptors were applied to the following databases: "Literatura Latino-Americana e do Caribe em Ciências da Saúde" (LILACS), Medical Literature Analysis \& Retrieval System on-line (Medline), "Base de Dados de Enfermagem" (BDENF) and Scientific Eletronic Library Online (SciELO). Descriptors were combined in either pairs or trios, as summarized in Table 1, in order to search articles in those databases.

As means to present the data obtained, search strategy used Boolean operators 'AND', as shown in Figure 1, which resulted in 1303 articles. Among those, 1217 articles refer to Medline base, 55 articles refer to LILACS base, 36 articles refer to BDENF base, and 9 articles refer to SciELO base.

Inclusion criteria were the following: publication with full text, 10-year time span (2010 to 2020), Portuguese language, specific theme, and type of study (quantitative study, qualitative study, exploratory-descriptive, experience report, descriptive cross-sectional, and quantitative and qualitative convergent care research). Exclusion criteria were the following: articles older than 10 years (2010 - 2020), publication in other countries, absence of descriptors (or similar) as approved by DeCS not meeting the research question and, lastly, duplication of publication.

Final steps included qualitative analysis, reading all abstracts, and descriptive evaluation of previously selected articles, by taking into account the following

Table 1. List and groups of descriptors for either pair or triplet search

\begin{tabular}{|c|c|c|c|c|}
\hline Emergency nursing & AND & Patient transportation & AND & Air rescue \\
\hline Emergency nursing & AND & Air rescue & AND & Medical services \\
\hline Medical services & & AND & & Patient transportation \\
\hline Air rescue & & AND & & Emergency nursing \\
\hline Emergency nursing & & AND & & Air rescue \\
\hline
\end{tabular}

Authorship: The authors (2020). 
aspects: 'authorship', 'year', 'title', 'journal' and 'focus'. As a means to organize and simplify their presentation, Table 2 shows ordered data. Journals resulting from evaluation and application of both inclusion and exclusion criteria were the following: 'Revista de Enfermagem da Universidade Federal do Pernambuco' (online), 'Revista Brasileira de Enfermagem', 'Revista Brasileira de Geriatria e Gerontologia', 'Revista da Escola de Enfermagem da USP' e 'Revista Texto \& Contexto Enfermagem'.

\section{Results}

Articles were categorized in terms of nurse's performance in pre-flight, during the flight, and in postflight. In aforementioned areas, such categorization of results was used to evaluate nursing care protocols in aerospace environment.

In databases, 1306 articles were found but only 16 articles were selected as their content included the research question. After reading their abstracts, 3 articles were excluded as they did not address any aspect clarifying the research problem or they were integrative reviews themselves. After analytically reading articles in full and related exclusions, the sample reduced to 13 articles meeting all inclusion criteria.

As Tables 2 and 3 show, selected articles were organized in terms of discussion in order to elucidate the research problem while meeting general and specific objectives of the present study.

\section{Discussion}

When assessing nurses' role in air transportation of critically-ill patients in Brazil, some points must be clarified. Aiming at greater accuracy on air transport of patients in view of advanced life support, the four issues are here discussed: Assignments, Qualifications, Challenges and Protocols. In what follows, those topics were addressed as needed while subdivided into smaller classes and interspersed with each other.

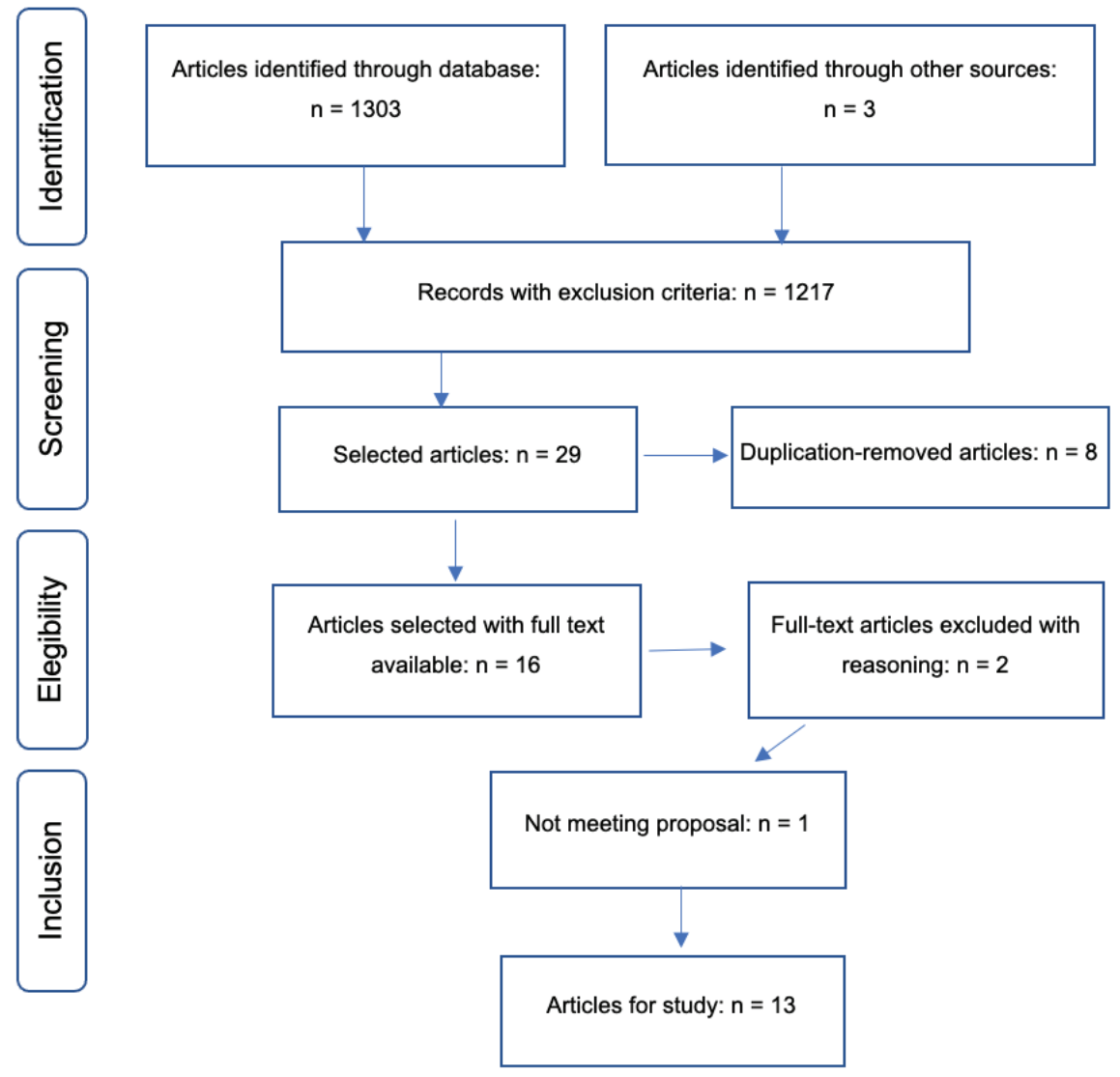

Figure 1. Flowchart of steps regarding evidence search in databases according to PRISMA, Limeira, São Paulo, Brazil, 2020

Authorship: The authors (2020). 


\section{Review article}

Table 2. Description of selected studies, Limeira, São Paulo, Brazil, 2020

\begin{tabular}{|c|c|c|c|c|}
\hline (N) & Study & Title & Place & Journal \\
\hline (1) & Camillo, Matsuda, 2017 & $\begin{array}{l}\text { Transcultural adaptation and validation of the } \\
\text { instrument PITTAETOOL for Brazil }\end{array}$ & Maringá (PR) & $\begin{array}{l}\text { Rev. Enfermagem } \\
\text { UFPE Online }\end{array}$ \\
\hline (2) & Pena et al., 2017 & $\begin{array}{l}\text { The importance of teamwork in patient air } \\
\text { transportation }\end{array}$ & Belo Horizonte (MG) & $\begin{array}{l}\text { Rev. Enfermagem } \\
\text { UFPE Online }\end{array}$ \\
\hline (3) & Raduenz et al., 2018 & Nurses' responsibilities in the aerospace environment & Florianópolis (SC) & $\begin{array}{l}\text { Rev. Brasileira de } \\
\text { Enfermagem REBEn }\end{array}$ \\
\hline (4) & Scuissiato et al., 2011 & $\begin{array}{l}\text { Flight nurses' comprehension about their role in the } \\
\text { multiprofesional team of aero-medical transport }\end{array}$ & Curitiba (PR) & $\begin{array}{l}\text { Rev. Brasileira de } \\
\text { Enfermagem REBEn }\end{array}$ \\
\hline (5) & Borges et al., 2020 & $\begin{array}{l}\text { Military Nursing in "Operation Return to Brazil": } \\
\text { aeromedical evacuation in the coronavirus pandemic }\end{array}$ & Rio de janeiro (RJ) & $\begin{array}{l}\text { Rev. Brasileira de } \\
\text { Enfermagem REBEn }\end{array}$ \\
\hline (6) & Nascimento et al., 2018 & $\begin{array}{l}\text { Elderly people receiving care through an aeromedical } \\
\text { service }\end{array}$ & Florianópolis (SC) & $\begin{array}{l}\text { Rev. Brasileira } \\
\text { de Geriatria } \\
\text { Gerontologia }\end{array}$ \\
\hline (7) & Schweitzer et al., 2018 & $\begin{array}{l}\text { Implementation of the protocol of nursing care in } \\
\text { trauma in aeromedical service }\end{array}$ & Florianópolis (SC) & $\begin{array}{l}\text { Rev. Brasileira de } \\
\text { Enfermagem REBEn }\end{array}$ \\
\hline (8) & Schweitzer et al., 2016 & $\begin{array}{l}\text { Emergency interventions for air medical services } \\
\text { trauma victim }\end{array}$ & Florianópolis (SC) & $\begin{array}{l}\text { Rev. Brasileira de } \\
\text { Enfermagem REBEn }\end{array}$ \\
\hline (9) & Bonin et al., 2016 & $\begin{array}{l}\text { Analyzer flow chart as a tool for aeromedical support: } \\
\text { descriptive study }\end{array}$ & Rio de janeiro (RJ) & $\begin{array}{l}\text { Rev. Escola de } \\
\text { Enfermagem USP }\end{array}$ \\
\hline (10) & Nardoto et al., 2010 & $\begin{array}{l}\text { The profile of victims attended by the Pernambuco } \\
\text { Prehospital Air Service }\end{array}$ & Recife (PE) & $\begin{array}{l}\text { Rev. Enfermagem } \\
\text { UFPE Online }\end{array}$ \\
\hline (11) & Schweitzer et al., 2012 & $\begin{array}{l}\text { Protocol of nursing care to traumatized patients in the } \\
\text { aerospace environment: care before flight }\end{array}$ & São José (SC) & $\begin{array}{l}\text { Rev. Brasileira de } \\
\text { Enfermagem REBEn }\end{array}$ \\
\hline (12) & Schweitzer et al., 2011 & $\begin{array}{l}\text { Nursing care protocol for trauma patients in the } \\
\text { aerospace environment - during and post-flight care }\end{array}$ & São José (SC) & $\begin{array}{l}\text { Texto Contexto } \\
\text { Enfermagem }\end{array}$ \\
\hline (13) & Banin et al., 2016 & Permanent education strategy for aeromedical support & Recife (PE) & $\begin{array}{l}\text { Rev. Enfermagem } \\
\text { UFPE Online }\end{array}$ \\
\hline
\end{tabular}

Authorship: The authors (2020).

The present work focused on field rescue and not on inter-hospital transportation, which requires protocols and application of distinct management models of on-board nursing. It should be observed that proper care towards the aircraft as well as boarding-deboarding safety processes are not addressed here, despite those requirements are among nurses' responsibilities.

Either in Brazil or abroad, there are two types of PHC, namely:BasicLifeSupport(BLS) and AdvancedLifeSupport (ALS).Specifically, the latter is a type of care exclusively performed by specialized physicians and nurses as it demands invasive and highly-complex maneuvers and care. ${ }^{9}$
As far as PHC is still concerned, the type of transportation directly influences client's survival rate, being one of the "golden hour" chain links. AMR has two types of transportation, namely: fixed-wing (airplanes) and rotary-wing (helicopters). The latter is mostly used because it dismisses landing strip while having easy vertical landings, besindes providing differentiated service in urban perimeter and in places of difficult access, as it reduces exposition time to the environment while reducing travel time to specialized centers. ${ }^{9-12}$

For most efficient nursing assistance in field, communication and teamwork are of great importance as 
Êmille M. de Morais et al. • Role of aerospace care nursing in Brazil: Integrative review

Table 3. Research outline, objective, main results and conclusion of articles selected for integrative review, Limeira, São Paulo, Brazil, 2020

\begin{tabular}{|c|c|c|c|}
\hline Study & Title & Place & Journal \\
\hline (1) Qualitative study & $\begin{array}{l}\text { Perform cross-cultural } \\
\text { adaptation and validation } \\
\text { of instrument The Pittsburg } \\
\text { Adverse Events Detection } \\
\text { and Classification Tool - } \\
\text { PittAETool for Brazilian } \\
\text { culture. }\end{array}$ & $\begin{array}{l}\text { Validation of the } \\
\text { instrument to classify and } \\
\text { identify adverse events in } \\
\text { aeromedical services in } \\
\text { Brazil. }\end{array}$ & $\begin{array}{l}\text { There is a long way for the instrument to } \\
\text { properly function in Brazil and professionals } \\
\text { must receive adequate training to objectively } \\
\text { apply it. }\end{array}$ \\
\hline (2) Qualitative study & $\begin{array}{l}\text { Understand daily work of } \\
\text { health professionals in air } \\
\text { transport of patients. }\end{array}$ & $\begin{array}{l}\text { There must be joint action } \\
\text { by team members in } \\
\text { order to carry out work of } \\
\text { excellence. }\end{array}$ & $\begin{array}{l}\text { Team's different interpretations and knowledge } \\
\text { are only efficient when there is interdisciplinary } \\
\text { involvement, which is a challenge to be } \\
\text { exercised on daily basis as it depends on several } \\
\text { factors such as unity, harmony, collaboration } \\
\text { and friendship with partnership at work. }\end{array}$ \\
\hline $\begin{array}{l}\text { (3) Exploratory- } \\
\text { descriptive, with } \\
\text { quantitative } \\
\text { approach }\end{array}$ & $\begin{array}{l}\text { Characterize nurses working } \\
\text { in aerospace environment } \\
\text { and identify most frequent } \\
\text { assignments developed } \\
\text { by them during pre-flight, } \\
\text { in-flight and post-flight } \\
\text { periods. }\end{array}$ & $\begin{array}{l}\text { Predominance of male } \\
\text { professionals, with average } \\
\text { performance time of } 6 \\
\text { years and main duties in } \\
\text { pre-flight, in-flight and post- } \\
\text { flight. }\end{array}$ & $\begin{array}{l}\text { Male activity predominates in this area } \\
\text { in contrast to what occurs in hospital } \\
\text { environment. Related reasons should be } \\
\text { discussed to eliminate gender prejudice in } \\
\text { the profession with respect to eliminating } \\
\text { inequalities and distinctions. In addition, } \\
\text { academic qualifications and training were } \\
\text { pointed as adequate for performance in critical } \\
\text { care settings. }\end{array}$ \\
\hline
\end{tabular}

\section{(4) Qualitative descriptive research \\ Identify how on-board nurses understand their role in multiprofessional aeromedical transport team

(5) Experience
repport \\ Describe the experience of military nursing in "Operation Return to Brazil" in an Aeromedical evacuation.}

Nurse manager of Aeromedical mission; nurse providing patient care; fundamental on-board nurse's competencies.

\section{Description of care} performed in pre-flight, screening and flight stages.
Aeromedical transport nurse acts as an element with team holographic vision in care, surpassing mechanical bases while adding expression and subjectivity to care.

\section{(6) Descriptive, transversal and quantitative}

\section{(7) Descriptive,} transversal and quantitative

\section{(8) Quantitative descriptive}

Characterize care provided to elderly people by Aeromedical Service in the Southern Region of Brazil.

Analyze the implementation of a nursing care protocol for trauma patients before, during and after flights.
Increase in gerontological cases, with greater demand on weekends, besides identifying main reasons for occurrences.
Careful care with nursing was described in all stages for suitable evacuation mission, although it was long and strenuous with passengers possibly contaminated back to Brazil.
Implementation of protocols and their efficient adherence.
With the increasing incidence of cases, it is necessary to create protocols aimed at assisting the elderly in urgent situations.
While most care has been already implemented, those not yet implemented may compromise care quality, thus demanding better service management and encouraging nurses to provide adequate care.

More studies are needed to create protocols in order to better approach traumatized people.
Analyze emergency interventions performed on trauma victims of aeromedical service, considering time at trauma scene and victims severity.
Verification of most used interventions and their incidence as well as the relationship between victims' severity and time on the scene. 


\section{Review article}

Table 3. Research outline, objective, main results and conclusion of articles selected for integrative review, Limeira, São Paulo, Brazil, 2020 (continued)

$\begin{array}{lll}\text { (9) Descriptive } & \begin{array}{l}\text { Analyze the process of } \\ \text { qualitative }\end{array} & \begin{array}{l}\text { Use of flowchart as } \\ \text { ieromedical activation in } \\ \text { the Air Operations Group of } \\ \text { Rio de Janeiro (RJ). }\end{array} \\ & \begin{array}{l}\text { managerial and operational } \\ \text { decisions of pre-hospital } \\ \text { care teams. }\end{array}\end{array}$

Permanent health education and publication

of the analyzer flowchart with criteria for triggering the aeromedical aim at demystifying this service among pre-hospital care professionals while expanding the use of this resource to population.

\begin{tabular}{|c|c|c|c|}
\hline $\begin{array}{l}\text { (10) Descriptive } \\
\text { exploratory } \\
\text { quantitative }\end{array}$ & $\begin{array}{l}\text { Quantitatively address the } \\
\text { profile of victims served by } \\
\text { pre-hospital air services in } \\
\text { Pernambuco state. }\end{array}$ & $\begin{array}{l}\text { Aeromedical service } \\
\text { demands and specifications. }\end{array}$ & $\begin{array}{l}\text { It is necessary to redefine and clarify } \\
\text { attributions among rescue workers, firefighters } \\
\text { and SAMU workers, while better articulating } \\
\text { PHC services with the hospital sector. }\end{array}$ \\
\hline $\begin{array}{l}\text { (11) Qualitative } \\
\text { convergent } \\
\text { assistance research }\end{array}$ & $\begin{array}{l}\text { Present a nursing care } \\
\text { protocol for aerospace pre- } \\
\text { removal. }\end{array}$ & $\begin{array}{l}\text { Demonstration of protocol } \\
\text { with care before the flight } \\
\text { together with reasoning. }\end{array}$ & $\begin{array}{l}\text { O protocolo propiciará uma prática de cuidado } \\
\text { mais segura aos pacientes aerorremovidos }\end{array}$ \\
\hline $\begin{array}{l}\text { (12) Qualitative } \\
\text { convergent } \\
\text { assistance research }\end{array}$ & $\begin{array}{l}\text { Identify the nursing care } \\
\text { necessary to build a service } \\
\text { protocol for traumatized } \\
\text { air-removed adult patients, } \\
\text { specific to periods during } \\
\text { and after flight, based on } \\
\text { Prehospital Trauma Life } \\
\text { Support principles. }\end{array}$ & $\begin{array}{l}\text { Demonstration of protocol } \\
\text { with care during and after } \\
\text { the flight together with } \\
\text { reasoning. }\end{array}$ & $\begin{array}{l}\text { By helping in decision-making, the protocol } \\
\text { will support nurses' care as based on } \\
\text { physiological changes resulting from the flight. } \\
\text { However, further studies aiming at nurse's role } \\
\text { with new protocols are still needed. }\end{array}$ \\
\hline $\begin{array}{l}\text { (13) Descriptive } \\
\text { qualitative study }\end{array}$ & $\begin{array}{l}\text { Identify educational } \\
\text { strategies to clarify } \\
\text { terrestrial APH teams } \\
\text { regarding the indications } \\
\text { for triggering aeromedical } \\
\text { assistance. }\end{array}$ & $\begin{array}{l}\text { Activation of aeromedical } \\
\text { service is below service } \\
\text { capacity. Service } \\
\text { professionals' insecurity } \\
\text { towards activation is the } \\
\text { main reason for this low } \\
\text { activation index. }\end{array}$ & $\begin{array}{l}\text { Permanent health education and restructuring } \\
\text { aeromedical activation process could } \\
\text { demystify this service among pre-hospital care } \\
\text { professionals while expanding the use of this } \\
\text { resource to population. }\end{array}$ \\
\hline
\end{tabular}

Source: The authors (2020).

physician-nurse joint action allows quality and safe care to patients. Accordingly, effective and noise-free communication is extremely important as it avoids conflicts and constraints. $12-14$

Connection in teamwork should be considered simultaneously with the articulation of numerous actions as performed by different professionals, i.e. physician, nurse and pilot. Communication between those team members must be oriented towards understanding actions to be performed in synergistic way. Without physician-nurse-pilot teamwork, simple events can lead to unwanted and even fatal setbacks to patients. ${ }^{14}$

By handling each step, nurses are mission managers. They are the professionals responsible for previously evaluating criteria to be followed in pre-flight and during the occurrence.

Assistance begins with forecasting and providing all inputs while collecting as much information as possible from patients and their health status. Accordingly, all necessary material must be selected for the mission, including blood bags, medicines, equipment and all supplies in general.

Yet, often, insufficient information about the case hinders quality care planning..$^{15}$ By anticipating any complications that may occur within this context, nurses must previously supply the selected aircraft and place materials therein. This task is accomplished along with physicians, thus exchanging knowledge. Still in pre-flight, patients' safety starts being implemented by planning care to be provided in conjunction with the multidisciplinary team..$^{10,15}$

During the entire rescue and aiming at patient's and team'ssafety, care team must keep frequentcommunication with pilots to check for possible complications. Schweltzer et al. ${ }^{9}$ show a care protocol from boarding to deboarding, including scene assessment along with each action reasoning.

Primary scene assessment consists of $\mathrm{ABCDE}$ sys- 
tem and main damage control. Actions to be performed before boarding include: advanced breathing procedures, CPR (cardiopulmonary resuscitation), medications for CPR, and bleeding control. In addition, team needs to have prior knowledge of flight physiology and patient stress factors ${ }^{9}$ in aerospace environment.9,13,16,17

During the flight, nursing main task is to monitor patients by aiming at their safety and well-being. Among these precautions, physiological changes due to aerospace environment must be observed while strictly monitoring vital signs, being nurses' main role.

Flights over 10,000 feet can affect oxygenation as hemoglobin rate drops very sharply, making blood oxygenation difficult. Nurses should also be mindful of loud noises from aircraft propellers. Main nursing interventions in direct care must prioritize airways, ventilation, oxygenation, bleeding control, perfusion, and neurological function. ${ }^{9,10,17}$

During the flight, nursing records should support patients' evolution while providing data to destination hospital. In post flight, nurses must deliver all data obtained, request responsible physician's signature at the institution, fill up the entire service form and carry out the shift change. ${ }^{10,17}$ Morever, nurses are responsible for delivering used material report, replacing those used materials, cleaning and disinfection equipment employed in care and, finally, delivering descriptive report of interventions and nursing care performed in mission. ${ }^{10,15}$

Connected to whole process of patient transportation, nursing must be conscious of risk groups, particularly the elderly, pregnant women and the immunocompromised. Therefore, nurses must create specific protocols to meet particularities of aforesaid groups to reduce sequelae and morbidity-mortality. For instance, changes resulting from aging may hinder patient transportation. ${ }^{11}$

In addition, there are extraordinary and unusual missions such as "Operation to return to Brazil". In order to evacuate Brazilian citizens from Wuhan in China, this mission had two specific goals, namely: (1) repatriation of 34 subjects and (2) obtaining more details about COVID-19. ${ }^{18}$ One nurse and three nursing technicians were assigned to this mission.

Yet little cited, systematization of nursing care (SNC) should be used throughout transportation from patient reception to case transfer to nurses at hospital. Importance of SNC stages becomes evident, which should be correctly performed from care assessment to its provision to patients in air transportation.

As already cited, teamwork is an implicit com- petence in aerospace sector so that it is essential that professionals learn how to relate well in work environment. Interaction among multidisciplinary team members creates a state of complicity, thus making them partners able to complet tasks with excellence, in which all parties are equally responsible. ${ }^{15,16}$ In order to reach complete partnership, nurses must acquire both technical and scientific knowledge so that training and improvement must be continuous, with permanent education being an important aspect to be considered.

As in any profession, on-board nursing is permeated with challenges, mostly including conflicts and emotions management. The work itself is stressful as it often deals with patient's worst moment in life, when errors can be lethal. In order to reduce the gap between technical-scientific knowledge and clinical practice, nursing and other health professions create and execute protocols to guide care sequence and prevent the occurrence of adverse events. ${ }^{19}$

In primary pre-flight assessment, initial actions must ensure airways (A) permeability and cervical spine control with either cervical collar or complete immobilization of victim on transport stretcher. Assistance consists of controlling upper airways through visual inspection of oropharynx while performing manual airway clearance and, if necessary, patient intubation. Advanced airway is used when necessary.9,10,13

Complete immobilization of victims reduces injuries incidence while decreasing pain. Immobilization should be done on head, neck, trunk and pelvis in neutral aligned position to prevent spinal cord injury. Further advantages of immobilization include easy constant evaluation and reduced effects of gravity during flight. ${ }^{9}$

As already cited, flying at high altitudes brings physiological changes and interventions must start in primary assessment. One alteration is gastric distention to be relieved or eliminated via nasogastric tube. However, this probe is contraindicated in suspected brain trauma (TBI - traumatic brain injury) and should be replaced by orogastric probe. Bladder indwelling catheter is intended to control water volume (in $\mathrm{mL} / \mathrm{h}$ ) and prevent bladder distension, but its use should be discussed with the medical team. ${ }^{9}$

In breath (B) assessment, it is necessary to verify whether the patient ventilates. If so, ventilatory frequency and inspiratory effort must be judged via chest observation and palpation while assessing accessory muscles usage. $^{13}$

Orotracheal intubation is mostly used as it allows ventilation at $100 \%$ oxygen, thus eliminating the 


\section{Review article}

risk of mask displacement while facilitating trachea aspiration. ${ }^{9}$ Identification of possible injuries such as pulmonary contusion can generate pneumothorax and hemothorax, being drained while still on ground. ${ }^{13}$

In the absence of spontaneous ventilation, assisted ventilation must be started through mechanical methods and nurses must evaluate and take due care. ${ }^{13}$ At the same time, nurses should instal the oximeter while being careful not to expose it to sun as it may provoke some changes. ${ }^{13,17}$

Circulation (C) assessment requires checking carotid pulse and, if it is absent, starting chest compressions and CPR protocol. Hemorrhage control is equally included herein. Situation control must be immediate and carried out before entering the aircraft; if necessary and pertinent, compressive dressings must be applied as means to control bleeding.13,17

In cases of severe bleeding when direct compression or compressive dressing does not completely interrupt blood flow, tourniquet can be used in despite the risk of small part or whole limb being sacrificed. To be used only in very severe bleeding, tourniquet must be close to the bleeding wound and tight enough to block arterial flow, being removed at definitive treatment place. $^{13}$

Nurses must obtain two calibrated accesses or one easily accessible inside the aircraft. Skin evaluation can indicate many factors. Cold skin might show possible shock due to decreased skin perfusion by compensation system. Pale or cyanotic skin points to insufficient blood flow due to vasoconstriction. In order to avoid puncture loss, bandage use is advised in air transportation. ${ }^{13}$

Disability (D) is linked to Glasgow coma scale ${ }^{13}$ and its evaluation with degree equal to or less than 8 suggests severe trauma in patient condition. After this scale classification, pupils state is evaluated through their reaction to stimulus and photoreaction. The health professional will check size, symmetry and reaction to light stimulus. Low score or score greater than 14 combined with anisochoric pupil may indicate severe brain injury. ${ }^{13}$ In suspicion of traumatic brain injury or skull base injury, nasogastric intubation is contraindicated due to false path risk; in this case, orotracheal probe is indicated. ${ }^{9}$

In exposure (E) to environment, care for patient's privacy and well-being is priority; team should only expose what is necessary for evaluation. In cases of burns, thermal blanket helps preventing hypothermia from heat and water losses; in addition, it helps maintaining temperature at high altitudes $\left(2{ }^{\circ} \mathrm{C}\right.$ loss every 1000 feet $)^{13}$

Acronym SHF (see - hear - feel) is used to optimize time during the second assessment, which is fundamentally caudal-brain inspection. ${ }^{13}$ Another precaution refers to using SAMPLE (signs-symptoms, allergies, medications, liquids-food, and environment). Accordingly, nurses can repeatedly assess the patient as a reminder of what to do. ${ }^{13}$

During the flight, main care has already been performed on ground so that nurses' main task is to keep patient stabilized until destination hospital. But there is still care to be performed inside the aircraft, namely:

A. Patient should be kept in neutral supine position to avoid spinal cord injury. ${ }^{20}$

B. Use of filters in intubated patients avoids unnecessary damage to airways, humidifying air while preventing staff exposure to aerosolized pathogenic microorganisms. Even in spontaneous ventilation, oximetry monitoring and oxygen administration should be accomplished in all patients so as to reduce hypoxia risk due to altitude elevation during flight. Ventilatory pattern must still be controlled and nurses must be attentive to pneumothorax signs, thus keeping chest drain open. ${ }^{20}$

C. Checking with multiparameter monitor allows the simultaneou observation of blood pressure, heart rate and oxygen saturation. Medication is administrated only if necessary and with signs of pain, agitation or nausea. ${ }^{20}$

D. Nurses should already leave sedatives within reach as traumatized people usually present agitation due to hypoxia. Another stress factor is discomfort due to sunlight, rendering headache, eye pain and dizziness. Nurses should also be aware of propellers effect that can yield seizures due to stroboscopic effect (i.e.effect produced by pulsating light source illuminating a moving object ${ }^{21}$ ) and, if necessary, lightly sedate patients or calm them down. ${ }^{20}$

E. Care in this stage aims at preventing any discomfort and incidents during transportation, in addition to providing maximum comfort.

Post-flight care is also nurses' responsibility, who must report care provided and trauma kinematics. All information about the patient is useful for treatment and care quality analysis as provided during transportation.

One of the great challenges of aerospace nursing is filling up the gap between analysis in field and practice. 
Discrepancy between the number of occurrences and the number of rescue requests is a warning to professionals in this area. Rescue requests are below service capacity, ${ }^{22}$ which is a disturbing issue in view of Brazil's territory and average rescue time of traumatized victim. Despite peculiarities and restrictions imposed, RAM is of paramount importance when time becomes a crucial factor between life and death.

There are still doubts among professionals about when air support should be called.23 In order to solve this issue, Permanent Education in Health (PEH) aims at establishing a protocol to resolve doubts and speed up rescue process. ${ }^{22}$ Bearing in mind quality of care provided, its main goal is to improve professional and organization practices in which they operate, thus helping nursing care meet population needs with quality, safety and efficiency.

\section{Study limitations}

Although considered reasonable in view of uniqueness and originality of the study theme, main limitation in the present review refers to the scarcity of articles answering the guiding question.

\section{Conclusion}

As this study can conclude, while nurses have worked in aeromedical removal crew since 1980s, standardization and establishment of nursing protocols for air transportation of patients are still lacking. Though

\section{Referências}

1. Rocha PK, Prado ML, Radunz V, et al. Assistência de enfermagem em serviço pré-hospitalar e remoção aeromédica. Rev Bras Enferm. 2003;56(6):695-698.

2. Gentil RC. Aspectos históricos e organizacionais da remoção aeromédica: a dinâmica da assistência de enfermagem. Rev Esc Enferm USP. 1997;31(3):452-467.

3. Bernades MMR, Lopes T. Enfermeiras do Exército Brasileiro no transporte aéreo de feridos: um desafio enfrentado na $2^{\mathrm{a}}$ Guerra Mundial. Rev Bras Enferm. 2007;60(1): 68-72.

4. Thomas RR, Miranda MFB, Souza GAG, et al. Enfermeiro de bordo: uma profissão no ar. Acta Paul Enferm. 1999;12(1):86-96.

5. Santos MMSC, Paulo RSS, Lima MAS, et al. Evolução sóciohistórica da saúde aeroespacial com enfoque na enfermagem: revisão integrativa. Cad Grad Ciênc Biol Saúde Fits. 2013;1(2):165-176.

6. Brasil. Ministério da Saúde. Portaria $n^{\circ} 2048$, de 5 de novembro de 2002. Regulamento Técnico dos Sistemas Estaduais dos Serviços de Urgência e Emergência. Brasília (DF): Ministério da Saúde; 2002.

7. Brasil. Decreto-lei $n^{\circ} 7.498$, de 25 de junho de 1986. Diário Oficial [da] República Federativa do Brasil, Poder Executivo, literature has aforesaid deficit, it was concluded that nurses' role in aeromedical transport is of paramount importance as only those professionals have technical-scientific knowledge to practice care management with quality, safety and effectiveness.

This article aims at encouraging nursing future students or professionals to research and fill up knowledge gaps about care systematization towards on-board nursing. Last but not least, on-board professionals working in pre-hospital rescue are expected to be able to confront problems and challenges in this area, by seeking more knowledge while developing skills for decision-making as supported by scientific evidence in any adverse situation.

\section{Recommendations}

Results from this study evidenced the need for further research on-board nursing, especially in view of current pandemic critical moment when on-board nursing becomes very important for interstate transportation of patients.

\section{Conflicts of interest / Competing interests}

Authors have no conflicts of interest to declare that are relevant to the content of the present work.

\section{Acknowledgements}

Authors would like to thank Prof. Dr. Jose A. Rabi for his contribution to the English version of the present work.

Brasília, DF, 26 de jun. de 1986, seção I, p.9273.

8. Souza MT, Silva MD, Carvalho R. Revisão integrativa: o que é e como fazer. Einstein. 2010;8(1):102-106.

9. Schweltzer G, Nascimento ERP, Nascimento KC, et al. Intervenções de emergências realizadas nas vítimas de trauma de serviço aeromédico. Rev Bras Enferm. 2017;70(1):54-60.

10. Raduenz SBDP, Santos JLG, Lazzari DD, et al. Atribuições do enfermeiro no ambiente aeroespacial. Rev. Bras. Enferm. 2020;73(4).

11. Nascimento KC, Fernandes CF, Girandi JBR, et al. Idosos atendidos em um serviço aeromédico. Rev. Bras. Geriatr. Gerontol. 2018;21(1): 82-90.

12. Nardoto EML, Diniz JMT, Cunha CEG. Perfil da vítima atendida pelo Serviço Pré-hospitalar Aéreo de Pernambuco. Rev. Esc. Enferm. USP. 2011;45(1):237-242.

13. Scwelzer G, Nascimento ERP, Moreira AR, et al. Protocolo de cuidados de enfermagem no ambiente aeroespacial a pacientes traumatizados: cuidados antes do voo. Rev. Bras. Enferm. 2011;64(6):1056-1066.

14. Peduzzi M. Equipe multiprofissional de saúde: conceito e tipologia. Rev Saúde Pública. 2001;35(1):103-9.

15. Scuissiato DR, Boffi LV, Rocha RR, et al. Compressão de enfermeiros de bordo sobre seu papel na equipe 


\section{Review article}

multiprofissional de transporte aeromédico. Rev. Bras. Enferm. 2012;65(4):614-620.

16. Dias CP, Ferreira FL, Carvalho VP. A importância do trabalho em equipe no transporte aéreo de pacientes. Rev. Enferm. UFPE on-line. 2017;11(6):2408-2014.

17. Schweitzer G, Nascimento ERP, Malfussi LBH, et al. Implementação do protocolo de cuidados de enfermagem no trauma em serviço aeromédico. Rev. Bras. Enferm. 2020;73(3).

18. Borges LL, Guimarães CC, Aguiar BGC, et al. Enfermagem militar na "Operação Regresso ao Brasil": evacuação aeromédica na pandemia do coronavírus. Rev. Bras. Enferm. 2020;73(2).

19. Camillo NRS, Matsuda LM. Adaptação transcultural e validação do instrumento PITTAETOOLL para o Brasil. Rev.
Enferm. UFPE on-line. 2017;11(11):4518-4523.

20. Schwelzer G, Nascimento ERP, Moreira AR, et al. Protocolos de cuidados de enfermagem no ambiente aeroespacial à pacientes traumatizados - cuidados durante e após o voo. Texto Contexto Enferm. 2011;20(3):478-485.

21. Albuquerque SA, Fraga FN, Santos RA. Revisão bibliográfica sobre os efeitos da radiação luminosa de lâmpadas eletrônicas na visão humana. Rev Eletrônica TECCEN. 2020;13(1):33-40.

22. Bonin WLM, Abrahão AL, Laprovita D, et al. Estratégia de educação permanente para o apoio aeromédico. Rev. Enferm. UFPE on-line. 2016;10(6):4757-4765.

23. Bonin WLM, Abrahão AL. O fluxograma analisador como ferramenta para o apoio aeromédico: um estudo descritivo. Rev. Enferm. UFPE on-line. 2016;10(5):4421-4423. 